CAS MUDDE

\title{
THE POPULIST RADICAL RIGHT: A PATHOLOGICAL NORMALCY
}

Willy Brandt Series of Working Papers
in International Migration and Ethnic Relations
$3 / 07$

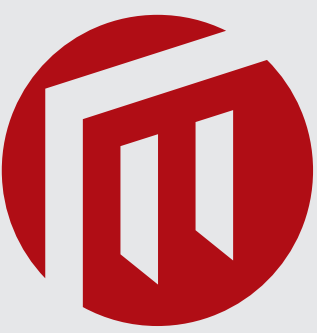




\title{
Willy Brandt Series of Working Papers in International Migration and Ethnic Relations 3/07
}

\author{
Published \\ 2008 \\ Editor \\ Pieter Bevelander \\ pieter.bevelander@mah.se \\ Editor-in-Chief \\ Björn Fryklund
}

\section{Published by}

Malmö Institute for Studies of Migration, Diversity and Welfare (MIM) and Department of International Migration and Ethnic Relations (IMER)

Malmö University

20506 Malmö

Sweden

Printed by

Holmbergs AB 2008

ISSN 1650-5743 / Online publication

www.bit.mah.se/MUEP 
Cas Mudde

\section{THE POPULIST RADICAL RIGHT: A PATHOLOGICAL NORMALCY}

In recent years more and more studies have pointed to the limitations of demand-side explanations of the electoral success of populist radical right parties. They argue that supply-side factors need to be included as well. While previous authors have made these claims on the basis of purely empirical arguments, this paper provides a (meta)theoretical argumentation for the importance of supply-side explanations. It takes issue with the dominant view on the populist radical right, which considers it to be alien to mainstream values in contemporary western democracies, expressed most explicitly in the "normal pathology thesis". Instead, it argues that the populist radical right should be seen as a radical interpretation of mainstream values, or, to stay in Scheuch and Klingemann's terminology, as a pathological normalcy. This argument is substantiated on the basis of an empirical analysis of party ideologies and mass attitudes. The proposed paradigmatic shift has profound consequences for the way the populist radical right and western democracy relate, as well as on how the populist radical right is best studied. Most importantly, it makes demand for populist radical right politics an assumption rather than a puzzle, and turns the prime focus of research on the political struggle over issue saliency and positions, and on the role of populist radical right parties within these struggles.

KEYWORDS: populism, radical right, political ideology, democracy 


\section{Introduction}

Today the politics of the radical right is the politics of frustration - the sour impotence of those who find themselves unable to understand, let alone command, the complex mass society that is the polity today (Bell 1964: 42).

The quote above could have been from any recent book on the contemporary radical right, but in fact dates from 1962, and summarizes Daniel Bell's assessment of the US radical right in the 1950s. It is indicative of a variety of dominant positions in the academic debate on the populist radical right, which I refer to here as the "normal pathology thesis" by Scheuch and Klingemann (1967). Short and simple, the thesis holds that the radical right constitutes a pathology in (postwar) western society and its success can only be explained by crisis. Authors working within this paradigm often consider the radical right in psychological terms and regularly use medical and psychological concepts.

This paper first provides a concise overview of the scholarship within the normal pathology paradigm, laying out the basic tenets of the thesis. It will argues that the thesis is not held up by empirical analysis; i.e. populist radical right attitudes and ideological features are rather widespread in contemporary European societies. This calls for a paradigmatic shift in the understanding of the contemporary populist radical right: from a normal pathology to a pathological normalcy. The paper finishes by outlying the most important consequences of this paradigmatic shift for the study of the contemporary populist radical right.

\section{The Normal Pathology Thesis Explained}

According to most scholarship on the populist radical right, (western) democracy and radicalism in general, and extremism in particular, are based upon fundamentally opposed values. In his political-historical study of political extremism, Uwe Backes (1989) defines extremism as antithetical to democracy. Radicalism is best defined as democratic, but anti-liberal democratic (Mudde 2007). Thus, both extremism and radicalism are challenging the fundamental values of contemporary western societies.

However, much scholarship on the 'far' (i.e. extreme and radical) right goes beyond the ideological opposition between radicalism and democracy, and consider the far right (in its various permutations) in psychological terms, mostly a pathology of modern society. The most influential studies in this tradition are the psychoanalytical analysis of fascism, such as Wilhelm Reich's The Mass Psychology of Fascism (1975; originally 1933) and 
Theodor W. Adorno and his collaborators' The Authoritarian Personality (1969; originally 1950). As research on the postwar radical right was heavily influenced by studies of historical fascism, it comes as no surprise that the pathology approach also dominates that field.

It seems that early scholarship on the postwar American radical right was particularly effected. For example, Daniel Bell's classic article "The Dispossessed" (1964) provides an analysis of the "psychological stock-intrade," rather than the ideology, of the radical right, and is filled with references to pathologies like paranoia and conspiracy thinking. Similarly, Richard Hofstadter, author of the influential article "The Paranoid Style in American Politics" (1964a), has argued that the radical right "stands psychologically outside the frame of normal democratic politics" (1964b: 102).

Many studies of the contemporary radical right in Europe have followed suit. References to paranoia and other psychological disorders abound in the politically inspired studies, which unfortunately still occupy a prominent position in the field (particularly in Germany and France). But even in serious scholarship populist radical right parties and supporters are often perceived in terms of a "normal pathology" (Scheuch \& Klingemann 1967); prominent authors that (used to) work within this tradition include Hans-Georg Betz (1994), Frank Decker (2004), and Michael Minkenberg (1998).

Scheuch and Klingemann's "theory of right-wing radicalism in western industrial societies" (1967) is, in fact, one of the most ambitious and comprehensive attempts at explaining the political success of radical right parties in postwar Europe, notably Germany, to date. The following description of the "normal pathology thesis" is therefore not to be seen as a summary of their theory, but rather as a simplified summary of one aspect of it, which has (unfortunately) been much more influential than the rest of the fascinating theoretical framework (Arzheimer \& Falter 2002). In short, the normal pathology thesis holds that populist radical right values are alien to western democratic values, but a small potential exists for them in all western societies; hence, a normal pathology. Within this paradigm, the support of populist radical right parties is based on "structurally determined pathologies” (Scheuch \& Klingemann 1967: 18).

\section{Normal Pathology and Academic Research}

The paradigm of the normal pathology thesis has profound effects on the academic study of the populist radical right. In its most extreme form, scholars study the phenomenon unrelated to mainstream democratic politics; i.e. not using mainstream concepts and theories, as the populist radical right is a pathology, and can thus only be explained outside of the 
'normal'. In most cases, this decision is at least as much political as it is scientific. Authors believe that by using mainstream concepts and theories, the scientist legitimizes the populist radical right.

This extreme interpretation was particularly prevalent in the study of the populist radical right in France, Germany, and the Netherlands in the 1980s and (most of) the 1990s. Many authors would focus almost exclusively on the historical links of the populist radical right, i.e. the link to prewar fascism and Nazism (e.g. Van Donselaar 1991; Schulz 1990). The assumption was that the postwar populist radical right had to be understood as a remnant of a distant past, not as a consequence of contemporary developments.

The more moderate form has always dominated studies of the electoral success of the populist radical right, and has become more broadly popular through the works of scholars integrating insights of the study of political parties (most notably the Greens) into the field (e.g. Kitschelt \& McGann 1995; Betz 1994; Ignazi 1992). In this moderate form, mainstream concepts and theories are employed, but the populist radical right is still perceived as an anomaly of contemporary western democracies.

The key puzzle in the normal pathology paradigm is demand: why does a popular demand for populist radical right politics exist? Two general answers are offered, protest and support, though both are based upon a similar assumption: under 'normal' circumstances only a tiny part of the population in western democracies has a demand for populist radical right politics. So, the search was on for those 'abnormal' circumstances in which 'populist radical right attitudes' spread. Most scholars find the answer in modern interpretations of the classic modernization thesis (Mudde 2007: 203-5).

Almost all major theories of populist radical right support within the normal pathology thesis refer to some form of crisis linked to some type of modernization process and its consequences: e.g. globalization, risk society, post-Fordist economy, postindustrial society (e.g. Swank \& Betz 2003; Loch \& Heitmeyer 2001; Holmes 2000; Beck 1992). The idea is always the same: society is transforming fundamentally and rapidly, this leads to a division between (self-perceived) 'winners' and 'losers,' and the latter will vote for the populist radical right out of protest (anger and frustration) or support (intellectual rigidity). In short, under conditions of massive societal change, the "losers of modernization" will vote for populist radical right parties (e.g. Decker 2004; Minkenberg 1998; Betz 1994; but also Bell 1964; Lipset 1955).

Importantly, within this approach populist radical right parties, and actually political actors in general, play hardly any role. The only internal (f)actor that is at times included is charismatic leadership (see Mudde 
2007: 260-3). This is not only in line with Max Weber's interpretation of charismatic leadership (Weber 1987 [1919]), although few authors refer explicitly to his theory, it is also in full accordance with the pathology thesis. As in 'normal' politics voting should be rational, based on ideology or at least identity (cleavage), not on an irrational bond with an individual.

In short, within the normal pathology thesis the populist radical right tends to be studied from either a fascism (extreme) or a crisis (moderate) perspective. The prime focus is on explaining demand, which should be low under 'normal' conditions. The supply-side of politics is almost completely ignored, as is the role of the populist radical right itself. As far as internal supply does enter the equation, it is in the form of charismatic leadership, again a perceived pathological remnant of a dark past.

\section{The Normal Pathology Thesis Assessed}

As so often with popular viewpoints, few people have ever tested the validity of the normal pathology thesis. Scheuch and Klingemann themselves laid out the theoretical framework in 1967, but never provided empirical evidence for it. Later scholars working within the tradition, most probably never read the rather obscure publication, seemed to treat the thesis as proven; received wisdom that no longer requires empirical proof.

In this section I assess the claim that the populist radical right is a normal pathology at two levels, the ideological and the attitudinal. First, I analyze whether its ideological core - defined as a combination of nativism, authoritarianism, and populism (Mudde 2007) - is indeed at odds with the basic values of western societies. Second, I examine whether populist radical right values are really shared by a (tiny) minority of the European population.

\section{The Ideological}

The key feature of the populist radical right ideology is nativism; i.e. an ideology, which holds that states should be inhabited exclusively by members of the native group ('the nation') and that nonnative elements (persons and ideas) are fundamentally threatening to the homogenous nation-state (Mudde 2007: 19). Nativist thinking has a long history in western societies, notably in the US, with movements like the "Know Nothings" dating back to the early $19^{\text {th }}$ century (e.g. Bennett 1990; Higham 1955).

Historically and ideologically, nativism is closely linked to the idea of the nation-state, a nationalist construction that has become a cornerstone of European and global politics. The idea of the nation-state holds that each nation should have its own state and, although this is often left implicit, each state should have only its own nation. Various European constitutions 
explicitly state that their country is linked to one nation; for example, the Slovak preamble starts with "We, the Slovak nation," while article 4.1 of the Romanian constitution states that " $(\mathrm{t})$ he foundation of the state is based on the unity of the Romanian people" (Mudde 2005: 172). The idea of national self-determination is even enshrined in chapter 1 , article 1 of the United Nations Charter, which explicitly calls for respect for the "selfdetermination of peoples."

This is not to claim that all references to national self-determination are necessarily expressions of nativism. For example, article 1 of the Constitution of Ireland states;

The Irish nation hereby affirms its inalienable, indefeasible, and sovereign right to choose its own form of Government, to determine its relations with other nations, and to develop its life, political, economic and cultural, in accordance with its own genius and traditions.

However, further articles express a fairly open attitude to non-natives, including "the firm will of the Irish Nation, in harmony and friendship, to unite all the people who share the territory of the island of Ireland, in all the diversity of their identities and traditions" (article 3).

But even where European states are not nativist, they will use "banal nationalism." With this term, Michael Billig (1995: 6) refers to everyday life "ideological habits which enable the established nations of the West to be reproduced." Simply stated, citizens in western countries are daily reminded of their "national identity" through a plethora of more and less subtle hints, ranging from the celebration of Independence Day, through the name of their media outlets (e.g. Irish Times, British Broadcasting Corporation, Hrvatska Radio Televizija), to history education in schools. Although banal reminders, they are based on the constituting idea of the nation-state.

Authoritarianism, the belief in a strictly ordered society in which infringements of authority are to be punished severely (Mudde 2007: 23), is a feature not even exclusive to the core of the populist radical right ideology. Most notably, "love and respect for authority," a euphemistic description of authoritarianism, is considered to be a core staple of conservatism (e.g. Layton-Henry 1982: 1). Moreover, authoritarianism is a key aspect of both secular and religious thinking, ranging from (proto-)liberals like Thomas Hobbes to socialists like Vladimir Ilyich Lenin, and from Roman Catholicism to Orthodox Christianity.

The third and final feature is populism, here defined as a thincentered ideology that considers society to be ultimately separated into 
two homogeneous and antagonistic groups, "the pure people" versus "the corrupt elite," and which argues that politics should be an expression of the volonté générale, i.e. the general will of the people (Mudde 2007, 2004). While the populist ideology has much deeper roots in the US than in (Western) Europe (e.g. Kazin 1998; Goodwyn 1976), key elements are clearly linked to fundamental values of western societies in general.

As Margaret Canovan (1999) so eloquently argued, democracy has a redemptive and a pragmatic side; the former emphasizes the idea(l) of $v o x$ populivox dei (or "government of the people, by the people, for the people"), the latter the importance of institutions. "Inherent in modern democracy, in tension with its pragmatic face, is faith in secular redemption: the promise of a better world through action by the sovereign people" (Canovan 1999: 11). Populism builds upon this "democratic promise" (Mény \& Surel 2002; Goodwyn 1976). Interpreting 'the people' as a homogenous moral entity, populists argue that the common sense of the people should always take precedent and cannot be curtailed by "undemocratic" institutional constraints such as constitutional protections of minorities.

Populism's anti-establishment sentiments are also closely connected to broadly shared beliefs in western societies. These range from Lord Acton's famous adagio "power corrupts" to the negative image of humanity so essential to Christianity (e.g. in the Original Sin). Indeed, the fact that evangelical Christianity plays a much greater role in the culture and politics of the US than in Europe, might be part of the explanation of the broader and deeper anti-establishment sentiments in that country. Moreover, whereas much of Western Europe had a more elite-driven process of democratization and state formation, based upon a strong central authority and an elitist distrust of the people, in the US the same processes were driven by "We, the People of the United States" and by a distrust in central government shared by both the masses and the elites, including the Founding Fathers.

\section{The Attitudinal}

The previous section has established that the constituent features of the populist radical right ideology are to a large extent in line with tenets of mainstream ideologies. Here, we will look into the overlap with mass attitudes. We mainly use the various Eurobarometer surveys, which is not only the only regular EU-wide socio-political survey, but it has also shown a particular interest in issues and values of relevance to this study.

Although nativism is not the same as racism, whatever that may actually mean to respondents, studies like the Eurobarometer provide ample evidence of extreme nativist attitudes within Europe. For example, Special Barometer 113 of December 1997, found that "(o)nly one in three of those 
interviewed said they felt they were 'not at all racist.' One in three declared themselves 'a little racist' and one third openly expressed 'quite or very racist feelings"” (ibid.:2).

More concretely, $65 \%$ of the EU-15 people agree with the statement that "our country has reached its limits; if there were to be more people belonging to these minority groups we would have problems" (ibid.:7). Almost two-thirds believe that all illegal immigrants should be sent back, while $80 \%$ believe illegal immigrants "convicted of serious offences" should be repatriated (ibid.:7). Even more radical than (most) populist radical right parties, some $20 \%$ support "wholesale repatriation," i.e. they agree with the statement that "all immigrants, whether legal or illegal, from outside the European Union and their children, even those born here, should be sent back to their country of origin" (ibid.:7).

Regarding authoritarianism, surveys show an even stronger overlap between mass attitudes and populist radical right positions. According to Special Barometer 181 of May 2003, 78\% of EU-15 citizens believe that young people would commit less crime if they were taught better discipline by their parents or at school (ibid.:9); ranging from $65 \%$ in Austria to $90 \%$ in France (ibid.:51). Similarly, $62 \%$ of EU-15 people believe that young people would commit less crime if jail sentences were tougher; however, varying between $37 \%$ in Sweden to $75 \%$ in Ireland (ibid.:10). Although $55 \%$ of EU citizens think their local police "are doing a good job" in fighting crime, $74 \%$ believe that "better policing" would reduce crime in their area (ibid.:47). Finally, a staggering $85 \%$ of the EU-25 populations agree with the statement: "Nowadays there is too much tolerance. Criminals should be punished more severely." This ranges from $70 \%$ in Denmark to $97 \%$ to Cyprus.

The ideological feature of populism can only be studied through its anti-elite or anti-establishment side. As the booming literature on Politikverdrossenheit has argued, and partly proven, growing groups of EU citizens hold negative attitudes towards the main institutions of their national democratic system, though not to the democratic system as such (e.g. Dahl 2000). In fact, in 1999, $40 \%$ of the EU-15 people were "not very satisfied" or "not at all satisfied" with their national democracy; ranging from $70 \%$ in Italy to $22 \%$ in the Netherlands (Eurobarometer 52, April 2000 ). Four years later, $46 \%$ of the EU-15 respondents claimed that they "tend not to trust" their national parliament, while percentages where 53 for the national government, and a staggering 75 for political parties, the main institutions of European democracies (Eurobarometer 59, April 2003).

Regarding the issue of corruption, a prominent staple of populist radical right propaganda, the Special Eurobarometer 245 ("Opinions on organized, 
cross-national border crime and corruption"), of March 2006, reported that $72 \%$ of EU-25 citizens believe that corruption is a major problem in their country. $59 \%$ believe that giving or receiving bribes is not successfully prosecuted. Of the categories that are believed to be corrupt, "politicians at national level" top the list, with $60 \%$ of the EU-25 respondents thinking they are corrupt; ranging from a low $29 \%$ in Denmark to a high $69 \%$ in Slovenia. Politicians at the regional level $(47 \%)$ and at the local level $(45 \%)$ are ranked fourth and fifth.

\section{From Normal Pathology to Pathological Normalcy}

The preceding analysis has shown that the normal pathology thesis does not hold up to empirical scrutiny. Populist radical right ideas are not alien to the mainstream ideologies of western democracy and populist radical right attitudes are not shared by just a tiny minority of the European population. In fact, the populist radical right is better perceived as a pathological normalcy, to stay within the terminology of Scheuch and Klingemann; well connected to mainstream ideas and much in tune with broadly shared mass attitudes and policy positions.

The pathological normalcy thesis does not entail that the populist radical right is part of the mainstream of contemporary democratic societies. Rather, it holds that, ideologically and attitudinally, the populist radical right constitutes a radicalization of mainstream views (cf. Betz 2003; Minkenberg 2001). The empirical argument is that key aspects of the populist radical right ideology are shared by the mainstream, both at the elite and mass level, albeit often in a more moderate form. Not surprisingly, this paradigmatic shift has a profound influence on (1) the relationship between the populist radical right and western democracy, and, consequently, (2) the study of the populist radical right.

With regard to the relationship between the populist radical right and western democracy, the key difference is not to be defined in kind, i.e. by fundamental opposition (i.e. antithesis), but in degree, i.e. by moderate versus radical versions of roughly the same views. Moreover, populist radical right attitudes and ideas are not marginal under normal conditions, they are fairly widespread, if often in a more moderate form than expressed by the populist radical right parties. How broadly shared the populist radical right ideology is, cannot (yet) be established on the basis of the available datasets. This would require a complex measurement model, encompassing a collection of multiple indictors for all three (multifaceted) ideological features, rather than simplistic indicators like left-right self-placement (e.g. Van der Brug et al., 2006) or support for racist movements. 


\section{Pathological Normalcy and Academic Research}

The paradigmatic shift from normal pathology to pathological normalcy has profound consequences for the academic study of the populist radical right. First and foremost, it means that the populist radical right should be studied on the basis of concepts and theories of mainstream political science (e.g. De Lange 2008). Second, the prime focus of the research should not be on explaining demand, as this is generated 'naturally' by the complex multiethnic western democracies, but on explaining supply.

For the populist radical right, the political struggle is not so much about attitudes, but about issues. After all, with regard to the issues that matter, i.e. the populist radical right trinity (corruption-immigration-security), a significant part of the population shares their positions to a large extent. The key point is that, traditionally, 'their' issues have not dominated the political struggle in most western democracies. Populist radical right parties do not focus primarily on socio-economic issues, as most traditional parties do, but on socio-cultural issues, like the other new party family, the Greens, does.

Within the pathological normalcy paradigm, understanding the success and failure of the populist radical right is, first and foremost, understanding the struggle over issue saliency and positions. In the terms of Paul Lucardie (2000: 175), populist radical right parties are purifiers, referring to "an ideology that has been betrayed or diluted by established parties," rather than prophets, "which articulate a new ideology". They do not have to sway voters to a new issue position, they have to shift them to a new issue: away from the socio-economic issues, like (un)employment, and towards the socio-cultural issues, like immigration. Therefore, the main struggle of the populist radical right party family is to increase the saliency of 'their' issues, i.e. corruption, immigration, and security.

The increased opportunities for electoral success for all populist radical right parties, at least since the mid 1980s, is to a large extent explained by this broader shift away from classic materialist politics towards some form of postmaterialist politics (Inglehart 1977), or at least a combination of the two. Within this process, the populist radical right itself played only a marginal role. Rather, it was to a large extent an unintended reaction to the success of the new left in the late 1960s and 1970s, which led to a neoconservative backlash in the late 1970 and 1980s (Ignazi 1992). This development not only created electoral space for the populist radical right, it opened up a relatively new and 'level' playing field; i.e. competition over socio-cultural issues like corruption, immigration, and security.

The fact that some populist radical right parties have been able to use these opportunities, and other have not, must be explained by the concept of 
“issue ownership" (Petrocik 1996: 826; also Budge \& Farlie 1983); or, more accurately, issue position ownership. While the new playing field was level in all countries, the struggle for issue position ownership varied. In some countries, new or reformed (right-wing) parties could capture issue position ownership on corruption, immigration, and security even before a populist radical right party was able to establish itself. In most unsuccessful cases, however, it was the populist radical right party itself that kept it from achieving issue position ownership. Because of a lack of organization and personnel, these parties were haunted by internal strife and public scandal, making them an unattractive political actor despite their favorable issue position.

Where the populist radical right was able to establish issue position ownership on one or more of their golden issues - corruption, immigration, security - the key explanation for their success was internal. While it was mostly the established parties (forced by the public and the media) that created the conditions for their electoral breakthrough, it was the populist radical right parties themselves that ensured their electoral persistence. Broadly stated, they did this through a combination of leadership, organization, and propaganda; although much more empirical study is needed to get a clearer view on what exactly defines successful from unsuccessful party organization, leadership, and propaganda.

\section{Conclusion}

In recent years more and more studies of the populist radical right have pointed to the limitations of demand-side explanations. Instead, they emphasize the need to include supply-side factors in the analyses as well (e.g. Carter 2005; Givens 2005). However, while previous authors have made these claims purely on the basis of empirical arguments, this paper provides the first (meta)theoretical argumentation for the importance of supply-side explanations.

The study of the populist radical right has been dominated by the normal pathology thesis, i.e. the belief that the populist radical right is a pathology of contemporary western democracies, which has only limited support under 'normal' circumstances. Within this paradigm, mass demand for populist radical right parties is the main puzzle, and can only be explained by some form of modernization theory related crisis.

However, as has been shown, the normal pathology thesis does not hold up under empirical scrutiny. The key features of the populist radical right ideology - nativism, authoritarianism, and populism - are not unrelated to mainstream ideologies and mass attitudes. In fact, they are best seen as a radicalization of mainstream values. Hence, the populist radical right should be considered a pathological normalcy, not a normal pathology. 
This paradigmatic shift has profound consequences for the study of the populist radical right. Widespread demand is a given, rather than the puzzle, in contemporary western democracies. Provocatively stated, the real question should not be why populist radical right parties have been so successful since the 1980 s, but why so few parties have been successful given the generally fertile breeding ground. The answer is to be found in the supply-side of issue politics, most notably in the struggles over the saliency of issues (particularly for the phase of electoral breakthrough) and over issue position ownership (especially for the phase of electoral persistence). This can only be truly understood if the populist radical right party itself is brought (back) into the analysis and explanation. 


\section{NOTES}

1 A notable exception is the chapter by Arzheimer and Falter (2002) in the Festschrifft for Hans-Dieter Klingemann. Not only do they put the normal pathology thesis to the test, they actually try to test the thesis in all its complexity.

2 Even in clearly multinational states or federations one can find such banal nationalism. The state of Belgium, for example, entails two large culturallinguistically different groups (Dutch speakers and French speakers; as well as a tiny group of German speakers), which do not even share one (monolingual) public space. At the same time, the Belgian Constitution explicitly states that "(a)ll power emanates from the Nation" (article 33; my italics).

3 EU-12 refers to the EU between 1980 and 1995, when it included the following twelve member states: Belgium, Denmark, France, Germany, Greece, Ireland, Italy, Luxembourg, Netherlands, Portugal, Spain, and the United Kingdom. In 1995, Austria, Finland and Sweden joined, transforming it into the EU-15. In 2004, ten new, mainly East European countries joined (Cyprus, Czech Republic, Estonia, Hungary, Latvia, Lithuania, Malta, Poland, Slovakia, and Slovenia), making it the EU-25. With the addition of Bulgaria and Romania, in 2007, the European Union is currently knows as the EU-27.

4 Few attempts at constructing such multidimensional measurement models have been undertaken so far. The few models that exist are heavily influenced by the models, not the theory, of Adorno and his collaborators. Unfortunately, they have been developed for different, if related, concepts (notably the "extreme right" and "far right"), and have been applied and tested in only limited local or regional contexts (see Meijerink et al. 1998, 1995; De Witte et al. 1994).

5 For example, Special Eurobarometer 41 on Racism and Xenophobia (November 1989) asked respondents whether the approved with "movements in favour of racism". Obviously, 'only' 4\% of EU-12 citizens approved "completely", and 6\% "to some extent" (ibid.:16).

6 In short, party A owns position $\mathrm{X}$ (on issue $\mathrm{Y}$ ) when a large part of the electorate that (1) cares about issue $\mathrm{Y}$ and (2) holds position $\mathrm{X}$, trusts party $\mathrm{A}$ to be the most competent party to shift policies (directly or indirectly) towards issue position $\mathrm{X}$. 


\section{REFERENCES}

Adorno, T.W., Else Frenkel-Brunswik, Daniel J. Levinson and R. Nevitt Sanford (1969) The Authoritarian Personality. New York. W.W. Norton.

Arzheimer, Kai and Jürgen W. Falter (2002) "Die Pathologie des Normalen. Eine Anwendung des Scheuch-Klingemann-Modells zur Erklärung rechtsextremen Denkens und Verhaltens", in Dieter Fuchs, Edeltraud Rolle and Bernhard Weßels (eds.), Bürger und Demokratie in Ost und West: Studien zur politischen Kultur und zum politischen Prozess. Festschrifft für Hans-Dieter Klingemann. Wiesbaden: Westdeutscher.

Backes, Uwe (1989) Politischer Extremismus in demokratischen Verfassungsstaaten. Elemente einer Rahmentheorie. Opladen: Westdeutscher.

Beck, Ulrich (1992) Risk Society: Towards a New Modernity. London: Sage.

Bell, Daniel (1964) “The Dispossessed”, in Daniel Bell (ed.), The Radical Right, Garden City, NY: Anchor, 1-45.

Bennett, David H. (1990) The Party of Fear. From Nativist Movements to the New Right in American History. New York: Vintage.

Betz, Hans-Georg (1993) "The New Politics of Resentment: Radical RightWing Populist Parties in Western Europe”, Comparative Politics, 25(4): 413-27.

Betz, Hans-Georg (1994) Radical Right-Wing Populism in Western Europe. Basingstoke: Macmillan.

Betz, Hans-Georg (2003) “The Growing Threat of the Radical Right", in Peter H. Merkl and Leonard Weinberg (eds.), Right-Wing Extremism in the Twenty-First Century, London: Frank Cass, 74-93.

Billig, Michael (1995) Banal Nationalism. London: Sage. 
Budge, Ian and Dennis J. Farlie (1983) Explaining and Predicting Elections: Issue Effects and Party Strategies in Twenty-Three Democracies. London: Allen \& Unwin.

Canovan, Margaret (1999) "Trust the People! Populism and the Two Faces of Democracy”, Political Studies, 47(1); 2-16.

Carter, Elisabeth (2005) The Extreme Right in Western Europe: Success or Failure?. Manchester: Manchester University Press.

Dahl, Robert A. (2000) “A Democratic Paradox?”, Political Science Quarterly, 115(1); 35-40.

Decker, Frank (2004) Der neue Rechtspopulismus. Opladen: Leske + Budrich.

De Lange, Sarah L. (2008) From Pariah to Power: Explanations for the Government Participation of Radial Right-Wing Populist Parties in West European Parliamentary Democracies. Antwerp: unpublished PhD thesis.

De Witte, Hans, Jaak Billiet and Peer Scheepers (1994) "Hoe zwart is Vlaanderen? Een exploratief onderzoek naar uiterst-rechtse denkbeelden in Vlaanderen in 1991", Res Publica, 36(1); 85-102.

Eurobarometer 52, April 2000.

Eurobarometer 59, April 2003.

Givens, Terri (2005) Voting Radical Right in Western Europe. New York: Cambridge University Press.

Goodwyn, Lawrence (1976) Democratic Promise: The Populist Moment in America. New York: Oxford University Press.

Higham, John (1955) Strangers in the Land: Patterns of American Nativism, 1860-1925. New Brunswick: Rutgers University Press.

Hofstadter, Richard (1964a) "The Paranoid Style in American Politics", Harper's Magazine, November, 77-86. 
Hofstadter, Richard (1964b) "Pseudo-Conservatism Revisited: A Postscript", in Daniel Bell (ed.), The Radical Right. Garden City, NY: Anchor, 97-103.

Holmes, Douglas R. (2000) Integral Europe: Fast-Capitalism, Multiculturalism, Neo-Fascism. Princeton: Princeton University Press.

Ignazi, Piero (1992) "The Silent Counter-Revolution. Hypotheses on the Emergence of Extreme-Right Wing Parties in Europe”, European Journal of Political Research, 22,(1-2);3-34.

Inglehart, Ronald (1977) The Silent Revolution: Changing Values and Political Styles among Western Publics. Princeton: Princeton University Press.

Kazin, Michael (1995) The Populist Persuasion: An American History. New York: Basic.

Kitschelt, Herbert and Anthony McGann (1995) The Radical Right in Western Europe. A Comparative Analysis. Ann Arbor: The University of Michigan Press.

Layton-Henry, Zig (1982) "Introduction: Conservatism and Conservative Politics", in Zig Layton-Henry (ed.), Conservative Politics in Western Europe. New York: St. Martin's, 1-20.

Lipset, Seymour Martin (1955) “The Radical Right: A Problem for American Democracy”, British Journal of Sociology, 6(2);176-209.

Loch, Dietmar and Wilhelm Heitmeyer (2001) Schattenseiten der Globalisierung. Rechtsradikalismus, Rechtspopulismus und Regionalismus in Westeuropa, Frankfurt am Main: Suhrkamp.

Lucardie, Paul (2000) "Prophets, Purifiers and Prolocutors: Towards a Theory on the Emergence of New Parties", Party Politics, 6(2); 175-185.

Meijerink, F.G.J., C.E. Mudde and J.J.M. Van Holsteyn (1995) "Rechtsextremisme: Opmerkingen over theorie en praktijk van een complex verschijnsel”, Acta Politics, 30(4); 165-178. 
Meijerink, Frits, Cas Mudde and Joop Van Holsteyn (1998) "Right-Wing Extremism”, Acta Politics, 33;165-178.

Mény, Yves and Yves Surel (2002) "The Constitutive Ambiguity of Populism", in Yves Mény and Yves Surel (eds.), Democracies and the Populist Challenge, Basingstoke: Palgrave, 1-21.

Minkenberg, Michael (2001) "The Radical Right in Public Office: AgendaSetting and Policy Effects", West European Politics, 24(4); 1-21.

Minkenberg, Michael (1998) Die neue radikale Rechte im Vergleich: USA, Frankreich, Deutschland. Opladen: Westdeutscher.

Mudde, Cas (2004) “The Populist Zeitgeist”, Government \& Opposition, 39(3),;541-63.

Mudde, Cas (2005) "Racist Extremism in Central and Eastern Europe", East European Politics and Societies, 19(2);61-84.

Mudde, Cas (2007) Populist Radical Right Parties in Europe. Cambridge: Cambridge University Press.

Petrocik, John R. (1996) "Issue Ownership in Presidential Elections, with a 1980 Case Study", American Journal of Political Science, 40(3); 825-850.

Reich, Wilhelm (1975) [1933] The Mass Psychology of Fascism, Harmondsworth: Penguin.

Scheuch, Erwin K. and Hans D. Klingemann (1967) "Theorie des Rechtsradikalismus in westlichen Industriegeselllschaften", Hamburger Jahrbuch für Wirtschafts- und Gesellschaftspolitik, 12, 11-29.

Schulz, Hans-Jürgen (ed.) (1990) Sie sind wieder da! Fashismus und Reaktion in Europa, Franfurt am Main:isp.

Special Eurobarometer 41, "Racism and Xenophobia”, November 1989.

Special Barometer 113, "Racism and Xenophobia: Human rights and immigration in the European Union”, December 1997. 
Special Barometer 181, "Public safety, exposure to drug-related problems and crime", May 2003.

Special Eurobarometer 245, "Opinions on organized, cross-national border crime and corruption”, March 2006.

Swank, Duane and Hans-Georg Betz (2003) "Globalization, the Welfare State and Right-Wing Populism in Western Europe", Socio-Economic Review, 1(2); 215-245.

Van der Brug, Wouter, Meindert Fennema and Jean Tillie (2006) "Why Some Anti-Immigrant Parties Fail and Others Succeed: A Two-Step Model of Aggregate Electoral Support", Comparative Political Studies, 38(5); 537-573.

Van Donselaar, Jaap (1991) Fout na de oorlog: fascistische en racistische organisaties in nederland, 1950-1990, Amsterdam: Bert Bakker.

Weber, Max (1987) [1919] Politik als Beruf, Berlin: Duncker \& Humblot, $8^{\text {th }}$ edition. 


\section{ABOUT THE AUTHOR}

Cas Mudde received his M.A. (1993) and Ph.D. (1998) in Political Science from the University of Leiden (the Netherlands). Before joining the University of Antwerp in July 2002, He taught at the Central European University (Budapest, Hungary) in 1998-99 and at the University of Edinburgh (Great Britain) in 2000-2002. Since being at Antwerp, he has been Fulbright EU Scholar-in-Residence at Rutgers, The State University of New Jersey (New Brunswick, USA) in the first half of 2006 and Willy Brandt Guest Professor at the Malmö Institute for Studies of Migration, Diversity and Welfare (MIM) in Sweden in April-May 2007.

He has further held short visiting positions at Academia Istropolitana Nova (Svätý Jur, Slovakia) in 1998, at Univerzita Karlova (Prague, Czech Republic) in 1999, at the University of California Santa Barbara (USA) in 2001, at University Jaume I (Castellón, Spain) in 2003, and at New York University (USA) in 2004.

He has also (co-)edited five books, including Racist Extremism in Central and Eastern Europe (Routledge, 2005), (with Roger Eatwell) Western Democracies and the New Extreme Right Challenge (Routledge, 2004) and (with Petr Kopecky) Uncivil Society? Contentious Politics in PostCommunist Europe (Routledge, 2002).

Among his recent journal articles are "Racist Extremism in Central and Eastern Europe" (East European Politics and Societies, Vol.19, No.2, 2005), (with Luke March) "What's Left of the Radical Left? The European Radical Left after 1989: Decline and Mutation" (Comparative European Politics, Vol.3, No.1, 2005), and (with Sarah de Lange) "Political Extremism in Europe" (European Political Science, Vol.4, No.4, 2005). In addition, he has (forthcoming) chapters in edited volumes on topics such as the foreign policy of the Dutch List Pim Fortuyn, anti-system politics in Europe, and civil society in Central and Eastern Europe.

Cas Mudde was Guest Professor in memory of Willy Brandt at IMER/MIM in Spring term 2007.

The Guest Professorship in memory of Willy Brandt is a gift to Malmö högskola financed by the City of Malmö, and sponsored by MKB Fastighets $A B$. It was established to strengthen ad develop research in the field of international migration and ethnic relations, and to create close links to international research in the field. 


\section{Willy Brandt Series of Working Papers in International Migration and Ethnic Relations}

1/01 Rainer Bauböck. 2001.

Public Culture in Societies of Immigration.

2/01 Rainer Bauböck. 2001.

Multinational Federalism:

Territorial or Cultural Autonomy?

3/01 Thomas Faist. 2001.

Dual Citizenship as

Overlapping Membership.

4/01 John Rex. 2003.

The Basic Elements of a Systematic

Theory of Ethnic Relations.

1/02 Jock Collins. 2003.

Ethnic Entrepreneurship in

Australia.

2/02 Jock Collins. 2003.

Immigration and Immigrant

Settlement in Australia:

Political Responses, Discourses

and New Challenges.

3/02 Ellie Vasta. 2003.

Australia's Post-war

Immigration - Institutional

and Social Science Research.

4/02 Ellie Vasta. 2004.

Communities and Social Capital.

1/03 Grete Brochmann. 2004.

The Current Traps of European

Immigration Policies.

2/03 Grete Brochmann. 2004.

Welfare State, Integration and

Legitimacy of the Majority:

The Case of Norway.

3/03 Thomas Faist. 2004.

Multiple Citizenship in a

Globalising World: The

Politics of Dual Citizenship in

Comparative Perspective.
4/03 Thomas Faist. 2004.

The Migration-Security Nexus:

International Migration and

Security before and after 9/11.

1/04 Katherine Fennelly. 2004.

Listening to the Experts:

Provider Recommendations

on the Health Needs of

Immigrants and Refugees.

2/04 Don J. DeVoretz. 2004.

Immigrant Issues and Cities:

Lesson from Malmö and

Toronto.

3/04 Don J. DeVoretz \& Sergiy

Pivnenko. 2004.

The Economics of Canadian

Citizenship.

4/04 Katherine Fennelly. 2005.

Correlates of Prejudice: Data

from Midwestern Communities in the United States.

1/05 Marco Martiniello. 2005.

Political Participation,

Mobilisation and Representation of Immigrants and Their Offspring in Europe.

2/05 Nikos Papastergiadis. 2005.

The Invasion Complex:

Deep Historical Fears and

Wide Open Anxieties.

3/05 Nikos Papastergiadis. 2005.

Mobility and the Nation:

Skins, Machines and Complex

Systems.

1/06 Sandro Cattacin. 2006.

Migration and differentiated

citizenship: On the (post-)

Americanization of Europe. 
2/06 Sandro Cattacin. 2006.

Why not "Ghettos"?

The Governance of Migration

in the Splintering City.

1/07 EvaMorawska. 2007.

International Migration:

Its Various Mechanisms

and Different Theories

that Try to Explain It.

2/07 Nina Glick Schiller \&

Ayse Çaglar. 2008.

Migrant Incorporation and

City Scale: Towards a Theory

of Locality in Migration

Studies.

3/07 Cas Mudde. 2008.

The Populist Radical Right:

A Pathological Normalcy. 
The Willy Brandt Series of Working Papers in International Migration and Ethnic Relations is a forum for research in, and debate about, issues of migration, ethnicity and related topics. It is associated with guest professorship in memory of Willy Brandt. Thus, the Series makes available original manuscripts by the Willy Brandt Guest Professors.

The guest professorship in memory of Willy Brandt is a gift to Malmö University financed by the City of Malmö, and sponsored by MKB Fastighets $\mathrm{AB}$. The Willy Brandt professorship was established to strengthen and develop research in the field of international migration and ethnic relations, and to create close links to international research in this field.

The Willy Brandt Series of Working Papers in International Migration and Ethnic Relations is available in print and online.

\section{MALMÖ UNIVERSITY}

SE-205 06 Malmö

Sweden

tel: +46 40-665 7000

www.mah.se 